\title{
Results of conservative treatment of angina pectoris in candidates for aortocoronary saphenous vein bypass
}

\author{
Lotfy L. Basta, J. Michael Kioschos, and Francois M. Abboud \\ From the Department of Internal Medicine, University of Iowa Hospitals, Iowa City, Iowa 52240, U.S.A.
}

The results of conservative treatment of 30 patients with symptomatic coronary disease who would have been genuine candidates for aortocoronary saphenous vein bypass graft surgery are reported. These patients had severe angina and at least 75 per cent occlusion of one or more coronary arteries associated with good distal run-off (diameter $2 \mathrm{~mm}$ or more distal to the obstruction) and adequate myocardial function. The patients were followed for a period of $I$ to 5 years.

Six patients had single vessel disease, 5 of whom improved and I deteriorated. Twelve patients had twovessel disease: 6 improved, 4 remained the same, I deteriorated, and I died. Twelve patients had three-vessel disease and none improved: 5 of them died, 4 deteriorated, and 3 remained the same.

Electrocardiographic findings correlated with the clinical course in patients with two-vessel disease; thus, 5 of the 6 patients who did not improve had electrocardiographic abnormalities at rest or after Master's exercise test, whereas 4 of the 6 patients who improved had normal resting and post-exercise electrocardiograms, and in one of the other cases the electrocardiogram became normal at follow-up.

It is suggested that many patients with single-vessel disease or two-vessel disease and normal electrocardiograms and who are currently considered for saphenous vein bypass surgery may have a favourable clinical course if treated conservatively.

Since the introduction of aortocoronary saphenous vein grafts to bypass proximal lesions in the main coronary arteries (Johnson et al., 1969), this operation has largely replaced all previously known surgical procedures employed in the treatment of ischaemic heart disease. However, while the operation was first intended for the symptomatic relief of angina pectoris, growing interest has extended the indications for this operation to cover most of the manifestations of ischaemic heart disease, including: acute coronary insufficiency (Auer et al., 197I; Segal et al., 1972), the early stages of myocardial infarction (Cohn et al., 1971; Hill et al., 197I), arrhythmia (Mitchell et al., 1970; Ecker et al., 197I), cardiogenic shock (Buckley et al., 197I), and heart failure (Johnson, Auer, and Tector, 1970).

The increasing enthusiasm for aortocoronary bypass operations probably arises from the lack of an effective treatment of atherosclerotic heart disease

Received 21 September 1972.

${ }^{1}$ Supported by a grant from the National Institutes of Health. and from the fact that this operation has been shown to be associated with an acceptable mortality (Danielson, Gau, and Davis, I97I ; Effler, Favaloro, and Groves, 197I) and that impressive relief of angina pectoris was often described after operation (Mitchel et al., 1970; Effler et al., 197I).

The natural history of angina pectoris has been identified (Block et al., 1952; Kannel and Feinleib, 1972), and the mortality has been correlated with the number of coronary arteries showing significant lesions on cineangiography (Moberg, Webster, and Sones, 1972), and with the electrocardiographic abnormalities at rest (Block et al., 1952) and after exercise (Robb and Marks, 1967; Blomquist, 1971). Despite this there have been no reports describing the clinical course of patients with disabling or increasing angina who are currently thought to be candidates for aortocoronary saphenous vein bypass surgery if these selected patients were treated conservatively with adequate medical therapy. Such reports would be expected to help in the evaluation of the merits of operation until an 
TABLE I Initial findings and follow-up data on patients with single-vessel disease:

\begin{tabular}{|c|c|c|c|c|c|c|c|c|c|}
\hline \multirow[t]{2}{*}{ Cases } & \multirow{2}{*}{$\begin{array}{c}\text { Age } \\
(y r)\end{array}$} & \multirow{2}{*}{$\begin{array}{l}\text { Blood } \\
\text { pressure } \\
(\mathrm{mmHg})\end{array}$} & \multirow{2}{*}{$\begin{array}{l}\text { Serum } \\
\text { cholesterol } \\
(\mathrm{mg} / \mathrm{I} 00 \mathrm{ml})\end{array}$} & \multirow{2}{*}{ Vessel affected } & \multicolumn{2}{|c|}{ Initial electrocardiogram } & \multicolumn{3}{|c|}{ Left ventricular function } \\
\hline & & & & & Rest & Exercise & $E F$ & $L V E D P$ & $A \mathrm{VO}_{2}$ \\
\hline MC & 58 & $128 / 60$ & 200 & Left circumflex $75 \%$ & Inferior infarction & - & 0.7 & 9 & $3 \cdot 8$ \\
\hline CW & 42 & $130 / 90$ & 185 & LAD $90 \%$ & $\mathrm{~T}$ inversion & - & 0.6 & 8 & 4.2 \\
\hline GJ & 52 & $150 / 100$ & 280 & LAD complete & Anterior infarction & - & 0.5 & 7 & $5 \cdot 1$ \\
\hline WN & 45 & $150 / 92$ & 202 & LAD complete & Normal & Negative & 0.7 & Io & $3 \cdot 8$ \\
\hline GH & 42 & $160 / 95$ & 340 & Left circumflex $90 \%$ & Normal & Positive & 0.7 & 8 & $4 \cdot 2$ \\
\hline HL & 36 & $130 / 80$ & 265 & LAD complete & Normal & Negative & 0.8 & Io & $3 \cdot 8$ \\
\hline
\end{tabular}

$\mathrm{EF}=$ ejection fraction; $\mathrm{LVEDP}=$ left ventricular end-diastolic pressure $(\mathrm{mmHg}) ; \mathrm{AV} \mathrm{O}_{2}=$ arteriovenous oxygen difference (vol. \%).

TABLE 2 Initial findings and follow-up data on patients with two-vessel disease:

\begin{tabular}{|c|c|c|c|c|c|c|c|c|c|}
\hline \multirow[t]{2}{*}{ Cases } & \multirow{2}{*}{$\begin{array}{l}\text { Age } \\
(y r)\end{array}$} & \multirow{2}{*}{$\begin{array}{l}\text { Blood } \\
\text { pressure } \\
(\mathrm{mmHg})\end{array}$} & \multirow{2}{*}{$\begin{array}{l}\text { Serum } \\
\text { cholesterol } \\
(\mathrm{mg} / \mathrm{I} 00 \mathrm{ml})\end{array}$} & \multirow{2}{*}{$\begin{array}{l}\text { Vessels significantly } \\
\text { diseased }\end{array}$} & \multicolumn{2}{|c|}{ Initial electrocardiogram } & \multicolumn{3}{|c|}{ Left ventricular function } \\
\hline & & & & & Rest & Exercise & $E F$ & LVEDP & $A V \mathrm{O}_{2}$ \\
\hline GL & 50 & $175 / 98$ & 245 & LAD complete, right $90 \%$ & Normal & Positive & 0.6 & 12 & $3 \cdot 8$ \\
\hline PG & 41 & $130 / 78$ & 215 & LAD $90 \%$, right $85 \%$ & Normal & Negative & 0.7 & 9 & $4 \cdot 2$ \\
\hline $\mathbf{B R}$ & 40 & $116 / 73$ & 360 & LAD complete, right $75 \%$ & Normal & Positive & 0.7 & 5 & 3.8 \\
\hline SM & 48 & $120 / 85$ & 260 & $\begin{array}{l}\text { LAD } 75 \%, \text { left } 75 \% \text {, } \\
\text { circumflex }\end{array}$ & Normal & Negative & 0.6 & 14 & $4 \cdot 3$ \\
\hline $\mathrm{AL}$ & 69 & $140 / 80$ & 200 & LAD $75 \%$, right complete & Abnormal & - & 0.7 & 5 & $4 \cdot 2$ \\
\hline KG & 39 & $140 / 80$ & 275 & LAD $85 \%$, right $90 \%$ & $\begin{array}{c}\text { Abnormal } \mathrm{T} \\
\text { inversion }\end{array}$ & - & 0.5 & 6 & $4 \cdot 7$ \\
\hline NE & 38 & $130 / 85$ & 250 & LAD 90\%, right $90 \%$ & Normal & Negative & 0.6 & 6 & $4 \cdot I$ \\
\hline ML & 56 & $126 / 66$ & 225 & Marginal $90 \%$, right $75 \%$ & Normal & Negative & 0.7 & Io & $4 \cdot 1$ \\
\hline $\mathrm{AK}$ & 45 & $130 / 90$ & 342 & LAD $90 \%$, right $75 \%$ & $\begin{array}{l}\text { Abnormal } \\
\quad \text { (infarction) }\end{array}$ & - & 0.5 & 8 & $4 \cdot 8$ \\
\hline NP & 50 & $120 / 80$ & 240 & $\begin{array}{l}\text { LAD } 90 \%, \text { left } \\
\text { circumflex } 75 \%\end{array}$ & Normal & Negative & 0.6 & 9 & $4 \cdot 0$ \\
\hline TG & 45 & $120 / 70$ & 285 & $\begin{array}{l}\text { Marginal 90\%, circum- } \\
\text { flex } 75 \%\end{array}$ & Normal & Positive & 0.65 & 8 & $3 \cdot 8$ \\
\hline DG & 42 & $150 / 90$ & 200 & $\begin{array}{l}\text { LAD complete, circum- } \\
\text { flex } 90 \%\end{array}$ & $\begin{array}{l}\text { Abnormal } \\
\text { (infarction) }\end{array}$ & - & 0.55 & I8 & $4 \cdot 8$ \\
\hline
\end{tabular}

TABLE 3 Initial findings and follow-up data on patients with three-vessel disease:

\begin{tabular}{|c|c|c|c|c|c|c|c|c|}
\hline \multirow[t]{2}{*}{ Cases } & \multirow{2}{*}{$\begin{array}{c}\text { Age } \\
(y r)\end{array}$} & \multirow{2}{*}{$\begin{array}{l}\text { Blood } \\
\text { pressure } \\
(\mathrm{mmHg})\end{array}$} & \multirow{2}{*}{$\begin{array}{l}\text { Serum } \\
\text { cholesterol } \\
(\mathrm{mg} / 100 \mathrm{ml})\end{array}$} & \multicolumn{2}{|l|}{ Initial electrocardiogram } & \multicolumn{3}{|c|}{ Left ventricular function } \\
\hline & & & & Rest & Exercise & $E F$ & $L V E D P$ & $A V \mathrm{O}_{2}$ \\
\hline MP & 39 & $128 / 80$ & 245 & Abnormal ST-T & 一 & 0.6 & 12 & $4 \cdot 8$ \\
\hline BS & 49 & $140 / 90$ & 255 & Normal & Positive & 0.7 & 14 & 4.6 \\
\hline CD & $4 \mathrm{I}$ & $140 / 90$ & 270 & Normal & Positive & 0.7 & II & $5 \cdot 2$ \\
\hline PW & 38 & $120 / 70$ & 223 & Normal & Inadequate & 0.7 & I0 & 4.4 \\
\hline $\mathrm{CV}$ & 54 & $155 / 88$ & 245 & Normal & Positive & 0.6 & 12 & $5 \cdot 0$ \\
\hline $\mathrm{CH}$ & 50 & $190 / 112$ & 293 & Abnormal, infarction & - & 0.55 & 14 & $5 \cdot 2$ \\
\hline LO & $5 I$ & $130 / 90$ & 224 & Abnormal, infarction & 一 & 0.48 & I0 & $5 \cdot 1$ \\
\hline $\mathbf{K R}$ & 42 & $140 / 90$ & 220 & Normal & Positive & 0.4 & 14 & 5.4 \\
\hline HR & 43 & $132 / 88$ & 280 & Normal & Positive & 0.6 & 12 & $4 \cdot 8$ \\
\hline PR & 55 & $130 / 100$ & 340 & Abnormal, infarction & - & 0.4 & 8 & 5.4 \\
\hline LM & 45 & $120 / 80$ & 215 & Normal & Positive & 0.7 & 5 & $4 \cdot 3$ \\
\hline RK & 43 & $100 / 60$ & 195 & Normal & Positive & 0.5 & 8 & $4 \cdot 4$ \\
\hline
\end{tabular}


average follow-up 24 months

\begin{tabular}{|c|c|c|c|}
\hline \multirow{2}{*}{$\begin{array}{l}\text { Follow-up } \\
\text { course }\end{array}$} & \multicolumn{2}{|c|}{ Follow-up electrocardiogram } & \multirow{2}{*}{$\begin{array}{l}\text { Follow-up } \\
\text { period } \\
\text { (mth) }\end{array}$} \\
\hline & Rest & Exercise & \\
\hline Improved & Old infarction & - & 48 \\
\hline Improved & Normal & Negative & 28 \\
\hline Improved & Old infarction & - & 24 \\
\hline Improved & Normal & Negative & 17 \\
\hline Deteriorated & Normal & Positive & 13 \\
\hline Improved & Normal & Negative & 12 \\
\hline
\end{tabular}

average follow-up 32 months

\begin{tabular}{|c|c|c|c|}
\hline \multirow{2}{*}{$\begin{array}{l}\text { Follow-up } \\
\text { course }\end{array}$} & \multicolumn{2}{|c|}{ Follow-up electrocardiogram } & \multirow{2}{*}{$\begin{array}{l}\text { Follow-up } \\
\text { period } \\
\text { (mth) }\end{array}$} \\
\hline & Rest & Exercise & \\
\hline Improved & Normal & Negative & $6 I$ \\
\hline Improved & Normal & Negative & 59 \\
\hline $\begin{array}{l}\text { Died } \\
\text { Improved }\end{array}$ & Normal & $\overline{\text { Negative }}$ & $\begin{array}{l}43 \\
37\end{array}$ \\
\hline Same & RBBB & - & 35 \\
\hline $\begin{array}{c}\text { Deteriorated, } \\
\text { infarction }\end{array}$ & Abnormal & 一 & 31 \\
\hline Improved & Normal & Negative & 29 \\
\hline Same & Normal & Positive & 26 \\
\hline Same & $\begin{array}{l}\text { Abnormal, old } \\
\text { infarction }\end{array}$ & 一 & 24 \\
\hline Improved & Normal & Negative & 13 \\
\hline Improved & Normal & Positive & 12 \\
\hline Same & Abnormal & 一 & 12 \\
\hline
\end{tabular}

average follow-up 23 months

\begin{tabular}{|c|c|c|c|}
\hline \multirow[t]{2}{*}{ Follow-up course } & \multicolumn{2}{|c|}{$\begin{array}{l}\text { Follow-up electro- } \\
\text { cardiogram }\end{array}$} & \multirow{2}{*}{$\begin{array}{l}\text { Follow-up } \\
\text { period } \\
\text { (mth) }\end{array}$} \\
\hline & Rest & Exercise & \\
\hline Died in office & - & - & 52 \\
\hline Died after MI and LVF & - & - & 3 \\
\hline Same & Normal & Positive & 54 \\
\hline $\begin{array}{l}\text { Deteriorated, angina at } \\
\text { rest, operation }\end{array}$ & Normal & Positive & 39 \\
\hline Same & Normal & Positive & 40 \\
\hline Died-infarction & - & - & $2 \mathbf{I}$ \\
\hline Pains at rest & Abnormal & - & 19 \\
\hline $\begin{array}{l}\text { Died - angina worse, } \\
\text { LVF }\end{array}$ & 一 & 一 & 5 \\
\hline $\begin{array}{l}\text { Deteriorated, increased } \\
\text { pain, operation }\end{array}$ & Normal & Positive & 15 \\
\hline Died - infarction & - & - & 3 \\
\hline Same & Normal & Positive & 15 \\
\hline $\begin{array}{l}\text { Increase in frequency } \\
\text { of pain }\end{array}$ & Normal & Positive & 14 \\
\hline
\end{tabular}

adequately controlled randomized study becomes available.

In this paper we report on the follow-up of 30 patients suffering from angina pectoris who were treated medically, but who would have been candidates for saphenous vein bypass operation according to our indications.

\section{Subjects and methods}

This study comprises 28 men and 2 women treated in the University of Iowa and the Veterans Administration Hospitals. Their ages ranged from 36 to 69 years. These patients were followed for a period of $I$ to 5 years (average 27 months) and were chosen from 192 patients who had undergone selective coronary cineangiography between 1967 and 1971 for suspected coronary artery disease. They fulfilled our present criteria for saphenous aortocoronary bypass procedure, i.e. (I) frequent attacks or a recent increase in the severity of angina pectoris; (2) with at least 75 per cent narrowing of one or more coronary arteries; (3) with good or fair distal runoff (vessel diameter of at least $2 \mathrm{~mm}$ distal to the obstruction); (4) with adequate myocardial function, i.e. ejection fraction more than 30 per cent, arteriovenous oxygen difference of less than 6 volumes per cent, and left ventricular end-diastolic pressure less than $20 \mathrm{~mm}$ Hg. We excluded from this analysis patients with diffuse coronary artery disease and those with associated valvular disease or large myocardial aneurysms; as in these latter patients, the prognosis is influenced by the associated disease. All 30 patients were treated conservatively since aortocoronary bypass operation was not then performed at the University of Iowa Hospitals. The medical treatment included control of the risk factors for coronary disease, and, in the majority of cases, with a combination of propranolol $160-240 \mathrm{mg}$ daily and sorbide nitrate $5 \mathrm{mg}$ sublingually 4 to 6 times daily.

These 30 patients were fully investigated, including electrocardiograms at rest and after Master's exercise test, right and left cardiac catheterization, and coronary cineangiography using the standard techniques. Left ventricular volumes and ejection fraction were calculated using the method described by Dodge, Hay, and Sandler (1962).

The patients selected for this report and who survived the follow-up period were re-evaluated, including clinical examination and electrocardiograms at rest and on graded treadmill exercise test. The stage at which a patient developed angina pectoris or significant ST abnormalities was noted and the findings were compared with the previous exercise electrocardiograms taken at comparable heart rates during the previous Master's test. Those who did not develop pain and/or ST abnormalities were allowed to continue until 85 per cent of the maximal heart rate predicted for their age, according to the method of Bruce and Hornsten (I969).

The patient's course was identified as follows:

I) Death: the follow-up period was taken as the period from the time of cineangiography until the time of death. 
2) Deterioration: an increase in the frequency of anginal attacks with decrease in the effort tolerance; development of a new myocardial infarction exclusive of the initial period in hospital or the development of left ventricular failure.

3) No improvement: the amount of exercise needed to precipitate angina did not change significantly at comparable heart rates, as observed during the treadmill exercise test. Some patients claimed that they had less frequent angina, but this apparent improvement was due to the patient's learning to avoid the precipitating causes of angina rather than to a real improvement in the effort tolerance.

4) Improvement: a decrease in the frequency of anginal attacks and an increase in effort tolerance, confirmed by observing the patients during the treadmill exercise test.

\section{Results}

\section{Patients with single-vessel disease}

Table I shows the findings and follow-up data of the 6 patients included in this group. Only one patient deteriorated over a period of 13 months in spite of adequate control of her hypertension, diabetes, and hyperlipidaemia. Of the 5 patients who improved, 2 patients developed myocardial infarction shortly after the initial study; subsequently they became free of pain. A third patient had recurrent ischaemic pain with ischaemic $T$ wave inversion over the anterior myocardial surface; he suffered a prolonged attack of pain not associated with enzyme increases after which he became free from angina pectoris and at present has a normal electrocardiogram and normal response to submaximal exercise test. Two others had normal electrocardiograms at rest and with double Master's exercise tests. The electrocardiograms remained normal and the patients showed clinical improvement.

\section{Patients with two-vessel disease}

Table 2 shows the findings and follow-up of the 12 patients included in this group. One patient died 43 months after the study; after an initial reported improvement the anginal pains increased in frequency and severity with subsequent inferior infarction, after which anginal pains persisted and the patient was found dead in bed. Another patient did not improve and sustained a myocardial infarction after 18 months and is presently under treatment for heart failure.

Of the 6 patients who improved on medical treatment, 2 became free from pain with negative exercise test. Fig. 2 shows the relation of the electrocardiographic findings to the clinical course in this group of patients. It is shown that of the 6 patients who improved, 4 had normal electrocardiograms at rest and after Master's exercise test, and a fifth

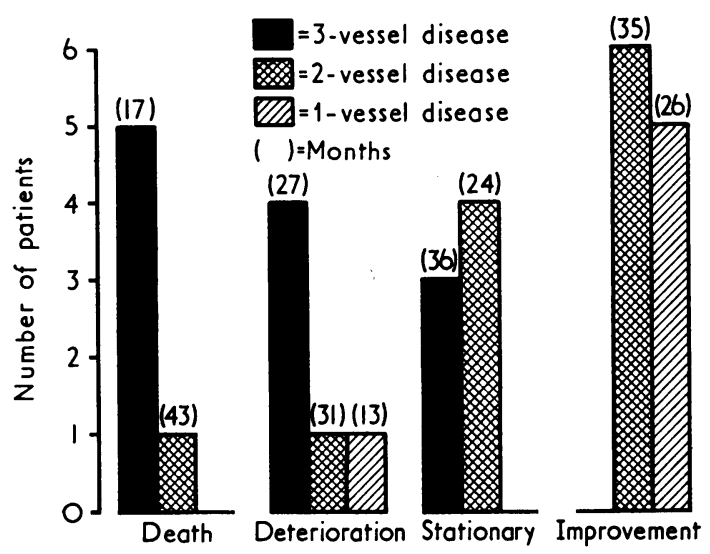

FIG. I The follow-up course in different groups of patients according to the number of vessels significantly occluded. The numbers on the columns indicate the mean follow-up period in months in each category.

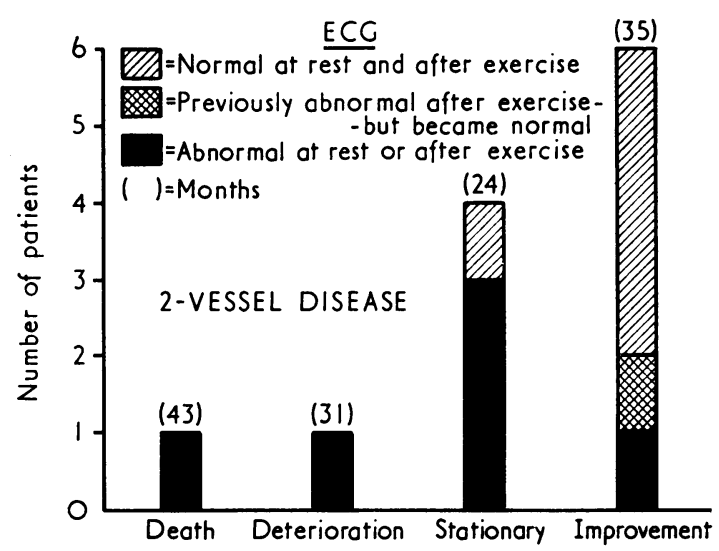

FIG. 2 The electrocardiographic findings and the clinical course in patients with two-vessel disease.

patient had, initially, a positive exercise test which became negative on follow-up. By contrast, 5 of the 6 patients who did not improve had abnormal electrocardiograms at rest or after exercise.

\section{Patients with three-vessel disease}

Table 3 shows the results and follow-up data on the I2 patients included in this group. Of the 5 patients who died during the follow-up period, 3 died within 5 months of the study, after worsening of angina and development of infarction in spite of medical therapy; I patient developed a myocardial infarction after $2 \mathrm{I}$ months of no improvement, and I patient, whose angiograms revealed extensive intercoronary collaterals, improved initially to a significant degree with obvious increase in the effort tolerance, but 
died suddenly after 52 months without premonitory symptoms. The 4 patients who showed deterioration in their symptoms claimed an initial symptomatic improvement on adequate medical therapy. These 4 patients were later operated upon after restudy coronary cineangiography which indicated no significant change from previous angiograms. Operation was performed 39, 21, 15, and 14 months after the initial study. No patient in this group with three-vessel disease exhibited convincing evidence of improvement at the follow-up study. All the patients included in this group had electrocardiographic abnormalities at rest or after exercise.

\section{Discussion}

One of the major difficulties encountered in assessing the efficacy of therapy for angina pectoris is the quantitation of improvement. The decrease in frequency of pain attacks and/or in the need for nitroglycerin tablets has generally been taken to indicate of improvement. Using these indicators alone, sham operations (Dimond, Kittle, and Crockett, 1960), unsuccessful operations ( Cobb et al., 1959; Dart et al., 1970; Balcon et al., 1970), and many forms of inappropriate medical therapy have been followed by favourable symptomatic relief. Therefore, we did not consider these as indications of improvement unless they were associated with an increase in the effort tolerance as obtained by careful analysis of the history and by observing the patients on graded treadmill exercise. It is notable that some of our patients who are reported as 'not improved' claim that they have been feeling significantly better.

The prognosis of patients with angina pectoris seems to follow the number of vessels affected. Thus, our patients with three-vessel disease had a significantly higher mortality $(P<0.05$ at two years' follow-up) than the rest of the patients, and the majority either died or deteriorated, while none showed sustained improvement over the follow-up period. These data conform with other studies indicating more than a threefold increase in the mortality figures in patients with three-vessel disease if compared to those with single-vessel disease (Moberg et al., 1972). In that study, the mortality figure for those with coronary disease limited to one vessel was nearly 3 per cent per year, which is not different from previously reported death rates among a control group of individuals not suffering from clinical coronary disease (Block et al., 1952).

Three patients with single-vessel disease presented initially with an acute onset angina that increased steadily over days or weeks and was followed by myocardial infarction in two of them and a more prolonged ischaemic attack without electrocardiographic or laboratory evidence of infarction in the third. Subsequently, all three patients became free from pain or other symptoms. Such a course conforms with the known clinical observation that angina pectoris is frequently ameliorated after myocardial infarction (Friedberg, 1966), and in view of the high incidence (almost 30\%) of myocardial infarction during aortocoronary saphenous vein bypass surgery in some series (Keelan et al., I97I), it is possible that such a mechanism might be at least partly responsible for the reported postoperative symptomatic relief.

The electrocardiographic findings were significantly $(P<0.05)$ helpful in predicting the subsequent course in patients with two-vessel disease. Among these patients, those who died, deteriorated, or failed to improve - with the exception of one had abnormal electrocardiograms either at rest or following Master's exercise test, while 5 of the 6 patients who improved had normal resting and postexercise electrocardiograms at follow-up. These observations are in accordance with previous studies that indicate a less favourable course for patients with angina pectoris and abnormal resting electrocardiograms (Block et al., 1952) or positive exercise tests (Robb and Marks, 1967).

Presently, some centres advocate bypass surgery for occluded coronary arteries regardless of the diameter of the vessel distal to the obstruction as seen in the cineangiograms (Glassman et al., 1971) and others might accept patients with poor myocardial function (Johnson and Lepley, 1970). In this study we did not include such cases because there is still controversy regarding the acceptability of these patients for operation. We thus attempted to present a selected group of patients that might be acceptable to most conservative centres. This study suggests, however, that many such patients, who are currently recruited for aortocoronary saphenous vein bypass operation, have a favourable course at least for a few years, irrespective of operation. In this favourable group, the merits of saphenous vein bypass operation have to be re-examined especially because the data available so far indicate that grafts might undergo occlusive changes not long after operation (Johnson et al., 1970; Grondin et al., I971; Vlodaver and Edwards, 1971), and that the myocardial function may or may not improve and might even deteriorate after operation (Johnson and O'Rourke, I97I; Keelan et al., 197I; Arbogast, Solignac, and Bourassa, 1972).

It is in the group of patients with the less favourable prognosis, despite full medical treatment, that the efficacy of operation has to be evaluated. Unfortunately, there is obvious discrepancy in the 
surgical results in this group of patients as reported in different series so that the immediate operative mortality figures vary from I to 47 per cent (Danielson et al., 1971; Mitchel et al., 1970; Johnson and Lepley, 1970), depending in part on the criteria for selection. The late postoperative results are even more difficult to define, and sufficient data might not be available for many years. In two recent reports, in which the patients were followed for a period of $\mathrm{I}$ to 30 months (Morris et al., 1972; Reul et al., 1972), impressive symptomatic improvement was reported in the majority of cases, even in those with multiple vessel disease. In that study, however, a lesion causing only 50 per cent narrowing of a coronary artery was considered significant and there is no definition of what parameters were taken to indicate improvement. In addition, the later follow-up results are not particularly discussed in terms of the number of the diseased vessels. Nevertheless, patients who reportedly did not improve usually had three-vessel disease, and a late incidence of myocardial infarction in II per cent of the operated group is noteworthy.

\section{References}

Arbogast, R., Solignac, A., and Bourassa, M. G. (1972). Ventricular volumes and ejection fraction one year after coronary vein-bypass-graft surgery (abstract). Clinical Research, 20, 36I.

Auer, J. E., Johnson, W. D., Flemma, R., Tector, A. J., and Lepley, D. (197I). Direct coronary artery surgery for impending myocardial infarction (abstract). Circulation, 44, Suppl. 2, 102.

Balcon R., Leaver, D., Ross, D., Ross, K., and Sowton, E. (1970). Clinical evaluation of internal mammary-artery implantation. Lancet, $\mathbf{x}, 440$.

Block, W. J., Crumpacker, E. L., Dry, T. J., and Gage, R. P. (1952). Prognosis of angina pectoris - observations in 6882 cases. Fournal of the American Medical Association, 150, 259.

Blomquist, C. G. (1971). Use of exercise testing for diagnostic and functional evaluation of patients with arteriosclerotic heart disease. Circulation, 44, I 120.

Bruce, R. A., and Hornsten, T. R. (1969). Exercise stress testing in evaluation of patients with ischemic heart disease. Progress in Cardiovascular Diseases, 11, 371.

Buckley, M. J., Mundth, E. D., Daggett, W. M., DeSanctis, R. W., Sanders, C. A., and Austen, W. G. (1971). Surgical therapy for early complications of myocardial infarction. Surgery, 70, 814.

Cobb, L. A., Thomas, G. I., Dillard, D. H., Merendino, K. A., and Bruce, R. A. (1959). An evaluation of internalmammary-artery ligation by double-blind technic. New England fournal of Medicine, 260, 1115.

Cohn, L., Fogarty, T. J., Daily, P. O., and Shumway, N. E. (1971). Emergency coronary artery bypass. Surgery, 70, 821.

Danielson, G. K., Gau, G. T., and Davis, G. D. (197I). Early results of vein bypass grafts for coronary artery disease (abstract). Circulation, 44, Suppl. 2, ror.
Dart, C. H., Scott, S., Fish, R., and Takaro, T. (1970). Direct blood flow studies of clinical internal thoracic (mammary) arterial implants. Circulation, 4I, Suppl. 2, 64.

Dimond, E. G., Kittle, C. F., and Crockett, J. E. (1960). Comparison of internal mammary artery ligation and sham operation for angina pectoris. American fournal of Cardiology, 5, 483 .

Dodge, H. T., Hay, R. E., and Sandler, H. (1962). An angiographic method for directly determining left ventricular stroke volume in man. Circulation Research, 11, 739.

Ecker, R. R., Mullins, C. B., Grammer, J. C., Rea, W. J., and Atkins, J. M. (197I). Control of intractable ventricular tachycardia by coronary revascularization. Circulation, 44, 666.

Effler, D. B., Favaloro, R. G., and Groves, L. K. (197I). Myocardial revascularization, Cleveland Clinic experience. Fournal of Cardiovascular Surgery, 12, 1.

Friedberg, C. K. (1966). Diseases of the Heart, pp. 744-746. W. B. Saunders, Philadelphia.

Glassman, E., Spencer, F. C., Tice, D. A., Weisinger, B., and Green, G. E. (197I). What percentage of patients with angina pectoris are candidates for bypass grafts ? Circulation, 43, Suppl. I, ror.

Grondin, C. M., Meere, C., Castonguay, Y., Lepage, G., and Grondin, P. (197I). Progressive and late obstruction of an aorto-coronary venous bypass graft. Circulation, 43, 698.

Hill, J. D., Kerth, W. J., Kelly, J. J., Selzer, A., Armstrong, W., Popper, R. W., Langston, M. F., and Cohn, K. E. (1971). Emergency aortocoronary bypass for impending or extending myocardial infarction. Circulation, 43, Suppl. I, 105.

Johnson, A., and O'Rourke, R. (197I). Effect of myocardial revascularization on systolic time intervals in patients with left ventricular dysfunction (abstract). Circulation, 44, Suppl. 2, 103.

Johnson, W. D., Auer, J. E., and Tector, A. J. (1970). Late changes in coronary vein grafts (abstract). American fournal of Cardiology, 26, 640.

Johnson, W. D., Flemma, R. J., Lepley, D., Jr., and Ellison, E. H. (1969). Extended treatment of severe coronary artery disease: a total surgical approach. Annals of Surgery, 170, 460.

Johnson, W. D., and Lepley, D. (1970). An aggressive surgical approach to coronary disease. Fournal of Thoracic and Cardiovascular Surgery, 59, 128.

Kannel, W. B., and Feinleib, M. (1972). Natural history of angina pectoris in the Framingham study - prognosis and survival. American fournal of Cardiology, 29, 154.

Keelan, M. H., Tresch, D. D., Co., E. H., and Lange, R. L. (197I). Incidence, mortality rate and sequelae of myocardial infarction immediately after coronary artery bypass surgery. Proceedings of the Central Society for Clinical Research, 44, 22.

Mitchel, B. F., Adam, M., Lambert, C. J., Sungu, U., and Shiekh, S. (1970). Ascending aorta-to-coronary artery saphenous vein bypass grafts. Fournal of Thoracic and Cardiovascular Surgery, 60, 457.

Moberg, C. H., Webster, J. S., and Sones, F. M. (1972). Natural history of severe proximal coronary disease as defined by cineangiography (200 patients, 7 year followup) (abstract). American fournal of Cardiology, 29, 282.

Morris, G. C., Reul, G. J., Howell, J. F., Crawford, E. S., Chapman, D. W., Beazley, H. L., Winters, W. L., Peterson, P. K., and Lewis, J. M. (1972). Follow-up results of distal coronary artery bypass for ischemic heart disease. American fournal of Cardiology, 29, 180.

Reul, G. J., Morris, G. C., Howell, J. F., Crawford, E. S., Sandiford, F. M., and Wukasch, D. C. (1972). Experience with coronary artery bypass grafts in the treatment of coronary artery disease. Surgery, 71, 586. 
Robb, G. P., and Marks, H. H. (1967). Postexercise electrocardiogram in arteriosclerotic heart disease: its value in diagnosis and prosnosis. Fournal of the American Medical Association, 200, 918.

Segal, B. L., Likoff, W., Van Den Broek, H., Adam, A., Blanco, G., Kimbiris, D., and Najmi, M. (1972). Saphenous vein bypass surgery for impending myocardial infarction (abstract). American fournal of Cardiology, 29, 290.
Vlodaver, Z., and Edwards, J. E. (1971). Pathologic changes in aortic-coronary arterial saphenous vein grafts. Circulation, 44, 719.

Requests for reprints to Dr. Lotfy L. Basta, Department of Internal Medicine, University of Iowa Hospitals and Clinics, Iowa City, Iowa 52240, U.S.A. 